\title{
Khasiat Tanaman Anting-Anting (Acalypha indica. L)
}

\author{
Ameilia Ameilia \\ Program Studi Sarjana Farmasi, Fakultas Farmasi, Universitas Padjadjaran, Sumedang, 45363 \\ email: ameiliaaaa4@gmail.com
}

\section{Abstrak :}

Indonesia adalah Negara yang memiliki sumber daya alam yang melimpah dan tersebar di berbagai penjuru pulau. Keanekaragaman hayati di Indonesia memiliki sekitar 30.000 spesies tanaman. Tanaman Herbal merupakan tumbuhan yang memiliki fungsi dalam pengobatan. Salah satu tanaman yang bisa digunakan sebagai obat yaitu tumbuhan Anting-anting (Acalypha indica. L). Tumbuhan anting-anting telah banyak digunakan secara turun-temurun sebagai obat disentri, diare, gangguan pencernaan, muntah darah, berak darah dan kencing darah, khususnya pada daun berkhasiat mengobati mimisan. Tumbuhan anting-anting memiliki rasa yang pahit. Akar pada tanaman anting-anting dapat digunakan untuk menurunkan kadar asam urat darah yang tinggi, meredakan nyeri pada rematik, pengobatan diabetes mellitus dan meredakan pegal linu.

Keyword : anting-anting, Acalypha indica. L, herbal

\section{Outline}

- Pendahuluan

- Apa yang dimaksud tanaman herbal?

- Apa saja khasiat dari tumbuhan anting-anting?

- Apa yang dimaksud dengan efek farmakologi?

- Antiradang

- Antibiotik

- Astringent

- Peluruh seni (Diuretik)

- Bagaimana cara mengkonsumsi tanaman anting-anting?

- Daftar Pustaka

\section{Pendahuluan}

Keanekaragaman hayati di Indonesia memiliki sekitar 30.000 spesies tanaman. Pada saat ini yang telah diketahui khasiatnya hanyalah sebanyak 9.600 spesies tanaman, tetapi yang digunakan sebagai bahan baku industri farmasi kurang lebih dari 283 tanaman (Kusuma dan Muhammad, 2005).

Saat ini mulai banyak bermunculan pemikiran negatif terhadap obat yang terbuat dari bahan kimia. Sehingga masyarakat mulai mencari obat-obatan yang terbuat dari bahan alam karena tidak menimbulkan efek samping yang berbahaya seperti bahan kimia. Hal ini menyebabkan peningkatan peranan pemanfaatan berbagai macam tanaman. 
Sekarang ini penggunaan produk berbahan herbal seperti herbal food, herbal cosmetics, herbal drink, hingga herbal medicine bukan hanyalah sebatas tren, namun sudah menjadi gaya hidup. Hal ini sejalan dengan kecenderungan masyarakat Indonesia untuk kembali ke alam (back to nature).

\section{Apa yang dimaksud tanaman herbal?}

Tanaman Herbal merupakan tumbuhan yang memiliki fungsi dalam pengobatan. Dimana yang dimaksud dengan herbal ialah semua jenis tanaman yang memiliki kandungan bahan atau zat aktif yang dapat digunakan untuk pengobatan. Sedangkan obat herbal adalah obat yang memiliki sifat organic atau alami yang sama seperti tubuh kita. Sehingga memiliki efek samping yang tidak berbahaya bagi manusia. Obat herbal murni dapat diambil dari sari pati tumbuhan maupun hewan yang memiliki manfaat untuk pengobatan tanpa adanya campuran dari bahan kimia buatan atau yang disebut dengan sintesis.

Salah satu tanaman yang bisa digunakan sebagai obat yaitu tumbuhan Anting-anting (Acalypha indica. L). Ciri-ciri tanaman anting-anting yaitu :

\section{Daun}

Tanaman anting-anting memiliki bentuk daun bulat lonjong. Letak daun tanaman ini berselang seling. Bentuk ujung dan pangkal daun tanaman anting-anting berbentuk lancing, sedangkan bagian pinggir daun bergerigi. Panjang daun tanaman ini ialah 2,5 $\mathrm{cm}$ hingga $8 \mathrm{~cm}$ serta lebarnya seitar $1,5 \mathrm{~cm}$ hingga $3,5 \mathrm{~cm}$.

\section{Batang}

Tanaman anting-anting banyak ditemukan di pinggir jalan, di lereng gunung dan di lapangan yang memiliki banyak rumput. Tanaman anting-anting memiliki ketinggian sekitar $30 \mathrm{~cm}$ sampai dengan $50 \mathrm{~cm}$. Batang tanaman anting-anting dapat bercabang serta memiliki garis kasar memanjang.

\section{Bunga}

Bunga tanaman anting-anting ialah bunga yang berumah satu dan memiliki kelamin tunggal. Bunga pada tanaman anting-anting muncul dari ketiak daun yang berbentuk kecil dalam rangkaian yang berupa malai.

\section{Buah}

Buah dari tanaman ini memiliki warna hitam dan berbentuk kecil.

\section{Apa saja khasiat dari tumbuhan anting-anting?}

Tumbuhan anting-anting telah banyak digunakan secara turun-temurun sebagai obat disentri, diare, gangguan pencernaan, muntah darah, berak darah dan kencing darah, khususnya pada daun berkhasiat mengobati mimisan. 
Tumbuhan anting-anting memiliki rasa yang pahit. Akar pada tanaman anting-anting dapat digunakan untuk menurunkan kadar asam urat darah yang tinggi, meredakan nyeri pada rematik, pengobatan diabetes mellitus dan meredakan pegal linu.

Selain dapat memberikan khasiat pada manusia, tumbuhan anting-anting dapat melancarkan pencernaan pada kucing. Karena itu cara yang dapat digunakan untuk meyakinkan bahwa tanaman tersebut adalah yaitu dengan cara mencabutnya hingga aar dan membiarkannya. Jika ada kucing yang memakan akarnya berarti tanaman tersebut adalah tanaman anting anting. Tumbuhan anting-anting memiliki efek farmakologi yaitu sebagai antiradang, antibiotik, astringent, dan peluruh seni. Menurut penelitian, senyawa yang terkandung dalam daun Anting-anting ialah aleuron, steroid, alkaloid, saponin dan flavonoid (Handayani et al, 2018).

\section{Apa yang dimaksud dengan efek farmakologi?}

Farmakologi merupakan sebuah ilmu yang mempelajari bahan-bahan yang berinteraksi dengan makhluk hidup melalui sebuah proses kimiawi khususnya melalui ikatan dengan molekul-molekul serta mengaktifkan atau menghambat proses-proses normal tubuh.

Bahan-bahan yang berupa kimia dan diberikan untuk mencapai sebuah efek terapeutik yang dapat berguna dalam suatu proses di dalam tubuh pasien atau untuk memberikan efek toksik terhadap proses-proses regulatorik dalam tubuh parasit yang menginfeksi pasien (Katzung et al, 2013).

\section{Antiradang}

Antiradang atau Anti inflamasi merupakan obat yang biasa digunakan untuk menghilangkan radang non infeksi atau bukan yang disebabkan karena mikroorganisme, tetapi yang muncul karena infeksi atau respon cedera jaringan. Agen dari anti inflamasi memiliki khasiat tambahan yaitu dapat meredakan rasa nyeri atau Analgesik, dan penurun panas atau Antipiretik.

\section{Antibiotik}

Antibiotik merupakan zat atau substrat yang dapat menghentikan pertumbuhan atau membunuh bakteri dengan cara menghambat fungsi penting dari sel bakteri. Antibiotik dapat digunakan untuk melawan infeksi bakteri pada manusia, hewan, dan tumbuhan. Namun antinotik tidak dapat digunakan untuk mengobati jenis-jenis penyakit yang timbul disebabkan oleh protozoa, jamur, virus, dsb.

\section{Astringent}

Astringent merupakan zat yang memiliki fungsi yang dapat mengecilkan pori-pori serta menghambat produksi minyak dalam jumlah berlebih pada kulit. 


\section{Peluruh seni (Diuretik)}

Fungsi peluruh seni atau diuretik ialah sebagai obat yang digunakan untuk membuang kelebihan air dan garam dari dalam tubuh melalui urin. Sehingga menyebabkan peningkatan kecepatan pembentukan urin.

\section{Bagaimana cara mengkonsumsi tanaman anting-anting?}

Seluruh bagian tanaman anting-anting baik segar maupun kering dapat dimanfaatkan untuk pengobatan. Seperti dalam mengobati beberapa penyakit sebagai berikut :

Berak darah, mimisan, dan batuk

Cuci 30-60 g tanaman anting-anting kering lalu direbus dengan 2 gelas air sampai tersisa 1 gelas. Dinginkan lalu minum 2 kali sehari masing-masing setengah gelas (Hariana, 2013).

\section{Disentri}

Cuci bersih 30-60 g tanaman anting-anting kering lalu direbus dengan 2 gelas air hingga tersisa 1 gelas. Dinginkan lalu minum 2 kali sehari masing-masing setengah gelas. Lakukan secara teratur selama 5-10 hari (Hariana, 2013).

Diare dan muntah darah

Rebus 30-60 g tumbuhan keing dengan 2 gelas air sampai tersisa 1 gelas, lalu dinginkan. Minum air rebusan 2 kali sehari- masing-masing 1/2 gelas (Hariana, 2013).

Pendarahan dan luka luar

Lumatkan herba anting-anting seger secukupnya lalu campurkan dengan gula pasir secukupnya. Tempelkan hasil lumatannya ke tempat luka (Hariana, 2013).

\section{Asam urat}

Cuci bersih tanaman anting-anting kering (seluruh batang) sebanyak 30-60 g, kemudian direbus dalam 3 gelas air sampai tersisa 2 gelas. Minum 2 kali sehari, masing-masing 1 gelas. Diminum sebelum makan pagi dan makan malam (Kusuma dan Muhammad, 2005).

Dermatitis, eksim, dan koreng

Cuci bersih tanaman anting-anting segar secukupnya, kemudian rebus. Gunakan airnya untuk mencuci bagian tubuh yang sakit (Kusuma dan Muhammad, 2005). 


\section{Daftar Pustaka :}

Handayani, Selpida et al. 2018. Profil Fitokimia dan Pemeriksaan Farmakognostik Daun Anting-Anting (Acalypha indica L.). Jurnal Fitofarmaka Indonesia. Vol.5(1) : 258-265.

Hariana, Arief. 2013. Tumbuhan Obat dan Khasiatnya. Jakarta : Swadaya.

Katzung, Bertram G. et al. 2013. Farmakologi Dasar dan Klinik. Jakarta : EGC.

Kusuma, Fauzi R. dan Muhammad Zaky. 2005. Tumbuhan liar berkhasiat obat. Jakarta : Agromedia pustaka. 